\title{
A Propaganda Model for Hollywood
}

\section{Matthew Alford}

University of Bath

Keywords: USA, Chomsky, foreign policy, Hollywood, power, Propaganda Model

\begin{abstract}
This article proposes a Hollywood Propaganda Model, based on Herman and Chomsky's original theory for news media, to explain the ideological output of mainstream Hollywood. The five filters are: concentrated ownership; the importance of merchandising; dependence on establishment sources; the disproportionate ability of the powerful to create flak; and a dominant ideology of 'us' versus the 'Other'. The article acknowledges the limits of such a model but makes the case that the filters are important overarching concerns in determining the 'bounds of the expressible' and that countervailing forces such as the supposed left-wing beliefs of grassroots Hollywood are of limited significance.
\end{abstract}

\section{A Propaganda Model for Hollywood}

Given the enduring applicability of Herman and Chomsky's approach to a range of public institutions (Herring and Robinson, 2003; Jensen, 2007; Phelan, 2006), it is somewhat surprising that the Propaganda Model has not been applied to Hollywood. Chomsky himself concedes that the avoidance of 'serious media critique right across the board' - for example, in motion pictures - 'is one respect in which the work that Ed Herman and I have done is really defective', adding that such aspects of social life are 'major part[s] ... of the whole indoctrination and propaganda system' $(2003,100)$. One reason for avoiding Hollywood, he later clarified, is that he simply does not 'know enough about movies' (2004). Alison Edgley observes that Chomsky also prefers easily verifiable, quantifiable empirical evidence and so is reluctant to engage in picture content, which is to a greater extent dependent on connotation rather than denotation (2000, 161-2) - although notably he is on record comparing On the Waterfront (1954) unfavourably with Salt of the Earth (1954) (2002). For his part, Herman explains that 'there is no logical reason' why films and other popular media should not 'be subject to the same general principles', even while he adds that 'there may be special factors of these media and local conditions that will modify the applicability of the propaganda model' (Klaehn, 2008).

Westminster Papers in Communication and Culture (C) 2009 (University of Westminster, London), Vol. 6(2): 144-156. ISSN 1744-6708 (Print); 1744-6716 (Online) 
The five filters can be re-appropriated for Hollywood quite readily to create a 'Hollywood Propaganda Model', resulting in films that do not challenge what Chomsky calls the 'bounds of the expressible' (1989, 45). Hence, almost without exception, mainstream Hollywood products will not only assume that the US is a uniquely 'worthy' and benevolent entity in world affairs but also will frequently endorse the application of US force against official enemies (with the resultant 'unworthy' victims). Certainly, there are countervailing factors in the industry, such as the individual political beliefs of filmmakers and the political tastes of audience markets, but these are relatively minor impediments to the generation of deradicalized texts. I demonstrate just how de-radicalized is the content of movies in a forthcoming book The Military-Industrial Dream Factory: How and Why Hollywood Supports US Foreign Policy (Alford, forthcoming). For the purposes of this article, however, I will explore how the filters work within the motion picture industry as a whole.

Guy Cumberbatch (2002) and Jenny Kitzinger (2002) have presented impressive cases of cultural products having significant effects on audiences, shifting away somewhat from the 'active audience' paradigm which was popular in the 1960 s. But this is not the focus of my article. The research presented here fits within a wider framework of contemporary visual discourse analysis, whose roots are in the Frankfurt School and which is now being used to examine films to see how they are 'systematically constructed to favour one point of view over others' (Van Leeuwen and Jewitt, 2000, 4). As Stuart Hall observed, media texts can be decoded for a 'preferred meaning' and these tend to reinforce the encoded 'dominant cultural order' (cited in Procter, 2004, 67). Antonio Gramsci calls this 'common sense', which he means not as a positive attribute but rather as a label for conformist modes of thinking that are resistant to 'change or correction' (ibid.). This research is also akin to the work of the Glasgow Media Group, which has demonstrated systematic pro-establishment bias in news media on a range of controversial issues such as the 1984/5 UK miners' strike, the 1990/1 Gulf War and, most recently, the Israeli-Palestinian conflict (Philo and Berry, 2004).

\section{The Hollywood Propaganda Model}

Concentrated Corporate Ownership

Herman and Chomsky's first filter fits Hollywood well. Just six theatrical film studios known collectively as 'the majors' control the vast majority of the world's movie business. These are: Disney (owned by the Walt Disney Company), Sony Pictures Entertainment (Sony), Paramount (Viacom Inc.), 20th Century Fox (NewsCorp), Warner Bros (TimeWarner Inc.) and Universal (General Electric/Vivendi). These companies produce, finance and distribute their own films, and also pick up projects initiated by independent filmmakers. The studios' parent corporations also have substantial holdings in other industries beyond 
entertainment and are well integrated into the prevailing order, which tames their output within standard ideological parameters (Bagdikian, 2004; McChesney, 2007). Indeed, elsewhere I observe that these parents even occasionally consciously interfere in the output of their subsidiaries, guided by their broader interests (Alford, forthcoming).

As Herman and Chomsky observe with regard to news media, the majors are subject to the 'sharp constraints' of the market and a collective interest in keeping production costs high to exclude weaker, less resource-rich rivals from taking their market share $(2008,14)$ hence the emphasis on expensive stars and special effects. In 2007 the average cost of producing and marketing a studio movie had reached $\$ 106.6$ million, after which the industry's practice of releasing such data was stopped (DiOrio, 2004). Smaller production companies have significant distribution capabilities in specialized markets, but generally these do not have the considerable access to capital or handle such broad theatrical product lines (Vogel, 2004, 49-50). There are overseas owners - NewsCorp (Australian), Vivendi (French), Sony (Japanese) - but Washington limits foreign ownership to 25 percent, provides various state subsidies and control of studio output remains in California and New York (Miller, 2005, 187-9). This has squeezed out competition from foreign films, which accounted for nearly 10 percent of the North American market in the 1960s, 7 percent by the mid 1980s, and just 0.5 percent by the late 1990s (McChesney, 2000, 33; Miller et al., 2001, 4).

What impact does this concentration of ownership among a very small group of US-based multinationals have on film content? First of all, while of course Hollywood is aware of its international markets, it is liable to make films about and for America and Americans, marginalizing the importance of foreigners. Second, films will tend to avoid political narratives that are unfamiliar to audiences. 'Filmmakers] don't do the unexpected, they're too scared - the prices are too high', says producer Robert Evans, who risked \$6.3 million to make The Godfather (1972) while head of Paramount Pictures. Evans estimates that today such a film would cost well in excess of $\$ 100$ million, which he thinks would scare most studios away from taking on such a risky project (Rich, 2005). Former President of Paramount David Kirkpatrick (2001) agrees the result is that: You need a homogenized piece of entertainment ... something that is not particularly edgy, particularly sophisticated.' That much is accurate, although Kirkpatrick's characterization of the resultant output as 'fluffy' is perhaps not so appropriate, given the positive portrayals of state brutality in distinctly non-fluffy films like Stargate (1994), Munich (2005) and The Kingdom (2007).

\section{Advertising}

Although movies are not dependent on advertising revenue (unlike most TV stations and newspapers), product placement and merchandising deals are 
widespread and attractive to movie-makers because, even if the movie fails, the manufacturer incurs the loss. Therefore, for financial security the major producers sell markets (film-goers) to buyers (advertisers). As such, the film producers compete for their patronage and - as Herman and Chomsky describe it with regards to news media - 'develop specialized staff to solicit advertisers and explain how their programs serve advertisers' needs' $(2008,16)$. Consequently, many films are under pressure to avoid raising 'serious complexities and disturbing controversies' because this would interfere with the 'buying mood' in the media outlet. Instead, they will more likely 'lightly entertain' and thus 'fit in with the spirit of the primary purpose of program purchases - the dissemination of a selling message' (ibid., 17-18). Egregious examples include the science fiction blockbuster Transformers (2007), which General Motors used as a 'once in a lifetime opportunity' to draw young people into the car market with extensive product placement (Schiller, 2007).

\section{Sourcing}

As Herman and Chomsky observe, government and corporate bureaucracies such as the Pentagon (Department of Defense) have vast and well funded public relations divisions, which ensure special access to the media $(2008,19-20)$. Unlike journalists, Hollywood creatives and producers do not rely on the Pentagon for daily news nor the military itself for protection in a war zone. However, filmmakers have made use of Pentagon advice and material to save costs and create authentic-looking films ever since the Oscar-winning Wings (1927), in exchange for carefully constructed script re-workings that ensure good coverage of the military for recruitment and public relations. Over a fifth of the well-financed films depicting the application of US force made between 1991 and 2002 across five genres received full cooperation from the Pentagon, including True Lies (1994), Executive Decision (1996), Air Force One (1997), Rules of Engagement (2000) and Black Hawk Down (2002). The CIA also appears to have exerted significant influence over films such as The Recruit (2003) and Charlie Wilson's War (2007), and there were even some unusually direct requests from Washington to Hollywood about how to represent the 'War on Terror' and the 'War on Drugs' (Alford and Graham, 2008).

\section{Flak and the Enforcers}

Punishment or 'flak' refers to the 'negative responses to a media statement or program' that 'may take the form of letters, telegrams, phone calls, petitions, law suits, speeches, bills before Congress, and other modes of complaint, threat, and punitive action' (Herman and Chomsky, 2008, 26). According to Herman and Chomsky, while flak may be organized locally or consist of 'entirely independent actions of individuals', the ability to produce effective flak is related to power (ibid., 26-28). The government is a major producer of flak, 'regularly assailing, threatening, and "correcting" the media, trying to contain any deviations from the established line', and the corporate community has also sponsored the creation of 
organizations like the right-wing Accuracy in Media (AIM) whose sole purpose is to produce flak (ibid., 27). This happened most dramatically with the 'Hollywood Blacklist', which began in 1947 and continued until the end of the 1950s, when filmmaking professionals were denied employment in the field because of their political beliefs or associations with Communism, whether verified or not.

On the occasions when radical movies do emerge that challenge US power, reactions from enforcers can be intense. Such attacks can come from all sides, though Eric Boehlert (2006) and Eric Alterman (2004) point to the highly organized right-wing attack machine, that has long run rings around its liberal opposition. For example, in 2008, the New York Post $(2006,14)$ reported that Hillary Clinton had ended her financial relationship with the Turkish producers of $V$ alley of the Wolves Iraq, a film that portrayed the US military as brutal invaders. Actress Jane Fonda, who broadcast anti-war messages on Radio Hanoi at the height of the Vietnam War, was maligned and even falsely imprisoned by the US government (Hershberger, 2004). 'All publicity' is not necessarily 'good publicity' when filmmakers knock up against the limits of tolerance in the US political system, just as journalists face risks when they embark on a dissident career path.

\section{Anti- 'Other' as a Control Mechanism}

Hollywood narratives are frequently based on polarized representations of good and evil, with the audience rooting for the 'good guys'. Throughout the Cold War, Communists provided convenient enemies in countless movies, from The Red Menace (1949) to Rambo III (1988) and beyond. Herman and Chomsky argue that Communism has always been seen by the powerful as the 'ultimate evil' because it 'threatens the very root of their class position and superior status' $(2008,29)$. Since the concept of Communism is 'fuzzy', it can be used against anyone 'advocating policies that threaten property interests or support accommodations with Communist states and radicalism' (ibid., 29). With Communism presented as the worst imaginable result, the support of abusive institutions abroad is 'justifiable' as a 'lesser evil' (ibid., 29). This presentation of the 'Other' feeds into a culture of irrational fears in East-West relations, examined by Adam Curtis' documentary series The Power of Nightmares (BBC Two, UK, 2004), which equates the US neoconservative movement with Islamic fundamentalism.

Herman concedes the filter perhaps should have been originally termed 'the dominant ideology', so as to include the merits of private enterprise and one's own government. In the end though, 'anti-Communism' was selected, primarily to emphasize the ideological elements that have been most important in terms of disciplining and controlling mechanisms (Herman, cited in Wintonick and Achbar, 1994, 108). 
Chomsky stresses 'Otherness' as part of the 'dominant ideology', explaining in The Common Good:

... it's the idea that grave enemies are about to attack us and we need to huddle together under the protection of domestic power. You need something to frighten people with, to prevent them from paying attention to what's really happening to them. You have to engender fear and hatred, to channel the kind of fear and rage - or even just discontent - that's being aroused by social and economic conditions (in Chomsky and Barsamian, 2003, 41).

The generation of 'Otherness' is well elucidated by commentators who address US and, more broadly, Western benevolence. Mark Curtis explains:

It is only we who are benevolent. As the New Statesman's John Lloyd has written: 'the defence of human rights - or more accurately, the aggressive promotion of human rights in an arena, such as Kosovo, where they are being brutalized - is a posture confined to the rich and secure world'. $(2005,380)$

After the end of the Cold War, it became fashionable to associate the Other with the East, particularly Islam and specifically its 'radical' form. Former National Security Council member Peter Rodman, writing in the National Review explained that 'now the West finds itself challenged from the outside by a militant, atavistic force driven by hatred of all Western political thought, harking back to age-old grievances against Christendom' (1992, 28). Harvard professor and founder of the Middle East Forum Daniel Pipes (1995) explains that in radical Islam there are 'no moderates' and that it is 'closer in spirit to other such movements (communism, fascism) than to traditional religion'. Harvard and Yale professor Samuel Huntington popularized the phrase 'Clash of Civilizations', claiming that the West had to face up to this new paradigm for international relations, and that Islam had 'bloody borders'. President George W. Bush took on similar rhetoric, initially dubbing his 'war on terror' 'Infinite Justice' and a 'crusade' (BBC News, 2001).

Edward Said (1979) explained that this kind of 'Orientalist' thought associated history, narrative, speech, complexity and development with the West, and image, stasis and myth with the East. For example, where the likes of Rodman and Bernard Lewis talk about 'the politics of rage' and Islam being driven by 'resentments' and 'material inferiority', Said asks: 'Does every one of the billion Muslims in the world feel rage and inferiority?' Said concludes that such assertions can be made because the Islamic stereotype 'stands charged and convicted without the need for supporting arguments or modulating qualifications' (1997, xviii).

This does not mean that the Other will necessarily be presented as wholly aggressive. Former editor of the New Left Review, Stuart Hall broadly concurs with Said's assessment and explains that: 
... for every threatening image of the black subject as marauding native, menacing savage or rebellious slave, there is the comforting image of the black as domestic servant, amusing clown and happy entertainer - an expression of both a nostalgia for an innocence lost forever to the civilized, and the threat of civilization being over-run or undermined by the recurrence of savagery, which is always lurking beneath the surface; or by an untutored sexuality threatening to 'break out'. $(1993,287)$

Ella Shohat and Robert Stam (1994) wrote about these binary representations of the Other in the movie genre, the Western, where different tribes of Indians become classified as 'good' (therefore to be patronized and rescued) or 'bad' (therefore to be destroyed). Shohat and Stam further argue that such a binarism "persists ... even in revisionist, "pro-Indian" (or "pro-Arab") films', with the result that stories are told from the perspective of the powerful (ibid., 109).

\section{Hollywood Activism}

The idea of applying a Hollywood Propaganda Model to explain de-radicalized movie output will seem anathema to those advocates of the conventional wisdom that Hollywood is a hotbed of left-wing activity.

Actually, liberal Hollywood has been remarkably unconcerned by American actions beyond its borders in the modern era. To illustrate, in the build-up to the 1991 Persian Gulf War, the Washington Post reported the Hollywood community's 'most visible liberals' are 'maintaining low profiles when it comes to the war' (Hall, 1991, D2). The 'fear' was that a protest of US policy could be misunderstood as a criticism of American troops (ibid.), as had occurred over Vietnam.

So, on the eve of the conflict, 100 Hollywood celebrities - including Tommy Lee Jones, James Woods, Jean-Claude Van Damme, Meryl Streep, William Shatner, Michelle Pfeiffer, Kurt Russell and Kevin Costner - recorded a charity record 'Voices That Care', which praised American troops without explicitly commenting on the legitimacy or otherwise of their presence in the Gulf. Lyrics included the following: 'Right or wrong, we're all praying you'll remain strong, that's why we're all here and singing along' - surely more toxic than anything Saddam Hussein dared to produce, since the early 1990s at least. When American troops returned home in April, Hollywood held a 'Welcome Home Desert Storm' parade, which deliberately excluded peace messages collated by a body of social activists (United Press, 1991).

Similarly, in the midst of NATO's bombing campaign against Serbia over the Kosovo Crisis in April 1999, an extensive interview with leading dissenting Hollywood stars appeared on the pages of The Nation, but none of them even 


\section{Alford, A Propaganda Model for Hollywood}

mentioned foreign policy, apart from actor Tim Robbins, who made a brief and pertinent comment alluding to the ongoing calamity in Iraq: 'You talk about the Hollywood Left, where the hell are they? The same people who will be absolutely crazy about animals being sacrificed in the name of medical research will not raise a voice about human beings who are killed in the name of oil' (Biskind, 1999, 14). Meanwhile, leading liberal activist and $M^{*} A^{*} S^{*} H$ star Mike Farrell actually did speak up - declaring he was 'in favor' of the war (Ehrenreich, 1999).

Even with regard to the exceptionally controversial 2003 Iraq War, Hollywood was split, with James Woods acting as a leading voice against the 'fraud' Michael Moore who had used his Oscar acceptance speech to criticize the President (Bonin, 2003). Lara Bergthold, former executive director of the Hollywood Women's Political Committee, which had been the town's most active opponent of the Reagan administration's interventions in South America during the 1980s, said that there was behind-the-scenes 'conversation' about the 'antiwar response', but that the debate 'should begin and take place in Washington' (Broder, 2002, 22), echoing the organization's lack of a public stance over Iraq in 1991 (Hall, 1991, D2).

Mostly, though, there has been apathy about US power in a political environment driven by money and narrow self-interest. Even right-wing activist David Horowitz, who despises what he sees as a liberal agenda in Hollywood, concurs, saying that ' $98 \%$ of people in Hollywood have no politics to speak of, or their politics are an inch deep. People do what they have to do to get ahead in this town' (Corn, 1999, 52). As a consequence, movie texts were produced according to the internal logic of the industry, which naturally strives for profit and is therefore subject to the filters of the Propaganda Model.

Additionally, although the political beliefs of celebrities are frequently discussed, in truth this is something of a side issue, and not necessarily a good methodological tool for understanding the communications industry. Justin Lewis observes in the documentary The Myth of the Liberal Media (Media Education Foundation, US, 1998) that studies examining the political beliefs of writers:

$\ldots$ assume that it is the journalists rather the owners, the advertisers, the news shapers or news makers that control the manufacture of news. That's a bit like saying ... the workers on the factory floor decide what the car industry produces.

The real owners, like Rupert Murdoch, have considerably different agendas from those of people further down the ladder.

Noam Chomsky explained further in the documentary: 
You could find that $99 \%$ of journalists are members of the socialist workers party or some Maoist group and that in itself would prove nothing about the media output. The issue is whether the media are free. Are the media by their institutional structure free to allow expression of opinion from whatever source and look at whatever topic and so on and so forth?

This is different from claiming that there is censorship of any kind in the media, even self-censorship. When British journalist Andrew Marr asked Chomsky, 'How can you know that I'm self-censoring?' Chomsky replied 'I don't say you're selfcensoring.... If you believed something different you wouldn't be sitting where you're sitting' (Marr and Chomsky, 1996).

Overall, Hollywood's opposition to US foreign policy in the contemporary era is all too easily exaggerated. Celebrity apathy towards, and complicity with, the stances of state and private power sets the context for understanding how entertainment conglomerates produce movies that invariably support the idea that the US is a benevolent power in world affairs and frequently endorse the application of US force.

\section{The Model's Limits}

In sum, then, Herman and Chomsky's Propaganda Model can be utilized, with minor adaptations, to explain the underlying politics of Hollywood output, as the organizational structures that drive film production are very similar to those of news producers. In fact, the ultimate owners of news-making and movie-making organizations are often one and the same.

This is not to say that the Hollywood Propaganda Model can explain every aspect of output. Jeff Goodwin criticizes Herman and Chomsky's model for failing to clarify 'the specific efficacy of each of its constituent elements' $(1994,103)$. Indeed, the model can be seen as 'too strong' because just one of the filters could be enough to account for the production of a particular story, leading to charges of over-determinism. However, as Herman explains, 'any model involves deterministic elements' so 'this criticism is a straw person unless the critics also show that the system is not logically consistent, operates on false premises, or that the predictive power of the determining variables is poor' (2003). Chomsky simply commented in an email to the author that 'there's no algorithm for judging relative importance [of each filter] abstractly. It varies from case to case’ (2006).

Jeffrey Klaehn (2003) points out in his reply to John Corner's (2003) criticism of the Propaganda Model: 'The model does not predict that the filter mechanisms "function without much if any need for further specification or qualification" (Corner)' (2003, 369). Klaehn goes on to say that the model constitutes 'a rich body of theory distinguished by its multiplicity of emphasis and focus' and asks 
rhetorically 'should the Propaganda Model be held up to what can be seen to be a higher standard than virtually every other conceptual model within the social sciences?' (ibid., 380).

Herman further explains that the original model deals with 'extraordinarily complex sets of events, and only claims to offer a broad framework of analysis, a first approximation, that requires modification depending on local and special factors, and that may be entirely inapplicable in some cases' (2003, 7). This remains true for the Hollywood Propaganda Model, which is able to elucidate the key factors to explain the positive representations of US power. Some commentators play up the countervailing forces in Hollywood, trying to push past the elephant in the room. For instance, Ben Dickenson argues that 'the fruit of the last twenty five years of activist and ideological battle in the arena of American cinema is the emergence in the twenty first century of a new radical Hollywood left' (2006, xiv), which has embarked upon a 'tumultuous path' to 'social justice' and whose influence, he declares, is dependent on 'how far they can understand the recent social, political and economic history' (ibid., xvi). Yet Marc Cooper points out that the 'authentic Hollywood left that functions beyond the parameters of narrow electoral politics' does exist but was 'virtually unchanged through the eighties and nineties ... because it is so small' (1999).

Beyond the five filters, in line with Herman and Chomsky's views on news media, it is true that filmmakers are sometimes able to use their positions and financial capital to challenge US power in particular, as with the highly unusual funding provided by e-Bay billionaire Jeff Skoll, who set up Participant Pictures in 2003. On the other hand, however, there remains the overwhelming desire for people to see themselves, and by extension, their nation, as basically good and decent - a premise which is reinforced by the idea that the US is a properly functioning democracy.

\section{Conclusion}

It is often claimed that in Hollywood if you want to send a message send a telegram'. In the narrowest sense this is a reasonable characterization: films do not tend to play party politics. But movies use politics in the broader sense constantly in the way they present the US, its enemies, its victims, the effectiveness of state violence and so on. In fact, it is not politics that is absent from Hollywood movies in terms of foreign policy, it is a sense of subversive or even rational politics interrogating the representations of the US, its enemies and its use of force - that has been carefully filtered out. The decisive reason for this is that films are produced by organizations closely wedded to elite power. As Jack Valenti, longtime President of the Motion Picture Association of America put it in 1998: 
Hollywood and Washington are 'sprung from the same DNA'. So, too, he could have added, are the upper echelons of corporate America.

\section{References}

Alford, M. (forthcoming) The Military-Industrial Dream Factory: How and Why Hollywood Supports US Foreign Policy, London: Pluto Press.

Alford, M. and R. Graham (2008) 'An offer they couldn't refuse', The Guardian 14 November.

Alterman, E. (2004) What Liberal Media? The Truth about Bias and the News, New York: Basic Books.

Bagdikian, B.H. (2004) The New Media Monopoly, Boston, MA: Beacon Press.

BBC News (2001) 'Infinite Justice, out - Enduring Freedom, in', 25 September.

Biskind, P. (ed.) (1999) 'On movies, money and politics: Beatty, Baldwin, Glover, Robbins, Stone and Lear', The Nation 5-12 April: 13-20.

Boehlert, E. (2006) Lapdogs: How the Press Rolled Over for Bush: New York: Free Press.

Bonin, L. (2003) 'Fighting words: celebrities feud about the war in Iraq. Politics gets personal for James Woods and Michael Moore, Chris Rock and Matt Drudge, and others', Entertainment Weekly 31 March, available at www.ew.com/ew/article/0,,439222,00.html (accessed 1 April 2009).

Broder, J.M. (2002) 'Threats and responses: Hollywood; celebrities known for political outspokenness have little to say about Iraq', New York. Times 6 October, section 1, p. 22.

Chomsky, N. (1989) Necessary Illusions: Thought Control in Democratic Societies, Boston, MA: South End Press.

Chomsky, N. (2002) Interviewed by various activists, An Exchange on Manufacturing Consent, http://www.chomsky.info/books/power02.htm (accessed 29 June 2009).

Chomsky, N. (2003) Understanding Power: The Indispensable Chomsky, New York: Vintage.

Chomsky, N. (2004) Personal email to Matthew Alford, 28 May.

Chomsky, N. (2006) Personal email to Matthew Alford, 10 December.

Chomsky, N. and D. Barsamian (2003) The Common Good, London: Pluto Press.

Cooper, M. (1999) 'Postcards from the left', The Nation 5 April, available at www.thenation.com/doc/19990405/cooper (accessed 29 April 2007).

Corn, D. (1999) 'Looking for Mr. Right: who's running the Conservative Club in town? David Horowitz's Wednesday morning club battles liberalism in Hollywood', The Nation 3(268), 5 April, pp. 52-7.

Corner, J. (2003) 'Debate: the model in question: a response to Klaehn on Herman and Chomsky', European Journal of Communication 18(3): 367-75.

Cumberbatch, G. (2002) 'Effects: media effects: continuing controversies', in A. Briggs and P. Cobley (2002) The Media: An Introduction, 2nd edn, London: Pearson Education Limited, pp. 258-71. 
Curtis, M. (2005) Web of Deceit: Britain's Real Role in the World, New York: Vintage.

Dickenson, B. (2006) Hollywood's New Radicalism: War, Globalisation and Movies From Reagan to George W. Bush, London: I.B Tauris.

DiOrio, C (2004) '15\% rise from previous year; Valenti confirms exit', Video Business, 23 March.

Edgley, A. (2000) The Social and Political Thought of Noam Chomsky, London: Routledge.

Ehrenreich, B. (1999) 'The war at home: local progressives talk about Kosovo', LA Weekly 5 May, available at www.laweekly.com/news/news/the-war-athome/6638/ (accessed 25 April 2007).

Goodwin, J. (1994) 'What's right (and wrong) about left media criticism? Herman and Chomsky's Propaganda Model', Sociological Forum 9(1): 101-11.

Hall, C. (1991) 'Quiet on the wartime set: actors slow to speak out on Gulf conflict', $W$ ashington Post 26 January, style section, final edition, p. D2.

Hall, S. (1993) 'Encoding, decoding', in S. During (ed.) The Cultural Studies Reader, London: Routledge.

Herman, E.S. (2003) 'The Propaganda Model: a retrospective', Against All Reason: Propaganda, Politics, Power 1, available at http://humannature.com/reason/01/herman.html (29 April 2007).

Herman, E.S. and N. Chomsky (2008) Manufacturing Consent: The Political Economy of the Mass Media, New York: Pantheon Books.

Herring, E. and P. Robinson (2003) 'Too polemical or too critical? Chomsky on the study of the news media and US foreign policy', Review of International Studies 29(4): 553-68.

Hershberger, M. (2004) 'Peace work, war myths: Jane Fonda and the antiwar movement', Peace and Change 29(3-4): 549-79.

Jensen, R. (2007) 'The faculty filter: why the Propaganda Model is marginalised in journalism schools', Windsor University Conference, Canada, 20 Years of the Propaganda Model, 15-17 May.

Kirkpatrick, D. (2001) 'Frontline interviews: the monster that ate Hollywood', Public Broadcasting Service (PBS), available at www.pbs.org/wgbh/pages/frontline/shows/hollywood/interviews/kirkpa trick.html (accessed July 2009).

Kitzinger, J. (2002) 'Impacts and influences: media influence revisited: an introduction to the "new effects research", in A. Briggs and P. Cobley (eds.) The Media: An Introduction, 2nd edn, London: Pearson: Longman, pp. 272-81.

Klaehn, J (2003) "Debate: Model Construction: Various Other Epistemological Concerns - A Reply to John Corner's Commentary on the Propaganda Model", European Journal of Communication, 18, pp. 377-383.

Klaehn, J. (2008) 'Media, power and the origins of the Propaganda Model: an interview with Edward S. Herman', Fifth-Estate-Online - International Journal of Radical Mass Media Criticism December. 
Marr, A. and N. Chomsky (1996) 'The big idea - interview with Noam Chomsky', BBC, available at www.zmag.org/Chomsky/interviews/9602-big-idea.html (accessed 15 June 2007).

McChesney, R.W. (2000) Rich Media, Poor Democracy: Communication Politics in Dubious Times, New York: New Press.

McChesney, R.W. (2007) Communication Revolution: Critical Junctures and the Future of Media, New York: New Press.

Miller, T. (2005) 'Hollywood, cultural policy citadel', in M. Wayne (ed.) Understanding Marxist Perspectives, London, Pluto Press, pp. 182-93.

Miller, T., N. Govil, J. McMurria \& R. Maxwell (2001) Global Hollywood, London: BFI.

New York Post (2008) 'Hill ousts bigot', 11 March, p. 14.

Phelan, S.E. (2006) 'Propaganda Model of business school behavior', Proceedings of the 4th International Critical Management Studies, 4-6 July 2005. Also in Quarterly Journal of Ideology 29, available at www.lsus.edu/la/journals/ideology/contents/vol29/vol1and2/Propagand amodelphelan.pdf (accessed 30 June 2007).

Philo, G. and M. Berry (2004) Bad News from Israel, London: Pluto Press.

Pipes, D. (1995) 'There are no moderates: dealing with radical Islam', National Interest Fall.

Procter, J. (2004) Stuart Hall, London: Routledge.

Rich, J. (2005) 'Monster budgets', Entertainment Weekly 853, 9 December.

Rodman, P. (1992) 'Islam and democracy', National Review 11 May, pp. 28-9.

Said, E. (1979) Orientalism, New York: Vintage Books.

Said, E. (1997) Covering Islam: How the Media and the Experts Determine How We See the Rest of the World, New York: Vintage.

Schiller, G. (2007) 'Firing on all cylinders', Hollywood Reporter 27 June.

Shohat, E. and R. Stam (1994) Unthinking Eurocentrism: Multiculturalism and the Media, London: Routledge.

United Press (1991) 'Hollywood's tribute to Gulf War vets rejects peace group', Section: Domestic News, United Press International, 27 April, BC Cycle.

Valenti, J. (1998) 'Hollywood and Washington: sprung from the same DNA', Speech before the Los Angeles World Affairs Council, 1 October, available at www.lawac.org/speech/pre $\% 20$ sept $\% 2004 \% 20$ speeches/valenti.html (accessed 27 March 2007).

Van Leeuwen, T. and C. Jewitt (2000) The Handbook of Visual Analysis, London: SAGE.

Vogel, H.L. (2004) Entertainment Industry Economics, 6th edn, Cambridge: Cambridge UP.

Wintonick, P. and M. Achbar (1994) Manufacturing Consent. Noam Chomsky and the Media: The Companion Book to the Award-winning Film, Montreal: Black Rose. 